\title{
INTERVENSI KEPERAWATAN TERHADAP SELF EFFICACY KELUARGA PASIEN SKIZOFRENIA
}

\author{
Rokhyati*' Meidiana Dwidiyanti, Sri Padma Sari \\ Program Studi Magister Keperawatan, Universitas Diponegoro \\ *rokhyatie@gmail.com
}

\begin{abstract}
ABSTRAK
Keluarga merupakan orang-orang yang terkena dampak langsung dari anggota keluarga penderita skizofrenia. Keluarga juga pihak yang menderita seperti halnya penderita skizofrenia, bahkan skizofrenia merupakan gangguan yang dapat berlangsung seumur hidup, menjadi beban finansial dan emosional yang berat serta berkepanjangan bagi keluarga. Keluarga menanggung beban stigma yang cenderung melekat kepada keluarga yang mempunyai anggota keluarga penderita skizofrenia. Keluarga dalam merawat penderita skizofrenia membutuhkan self efficacy. Intervensi keperawatan diperlukan untuk meningkatkan self efficacy keluarga, memperkuat strategi koping, mencegah kekambuhan skizofrenia, meningkatkan fungsi keluarga dan menurunkan beban keluarga. Literatur review ini bertujuan mengetahui intervensi- intervensi yang digunakan terhadap self efficacy keluarga dengan skizofrenia. Metode yang digunakan menggunakan review artikel dan Jurnal keperawatan dari tahun 2007 sampai dengan tahun 2018. Hasil berbagai intervensi yang dilakukan menunjukkan perubahan yang bermakna terhadap self efficacy.Simpulan perawat perlu mengetahui berbagai intervensi keperawatan terhadap self efficacy keluarga untuk meningkatkan kemampuan keluarga dalam merawat dan penerimaan terhadap penderita dengan skizofrenia. Saran perlu dikembangkan intervensi keperawatan untuk lebih meningkatkan selft efficacy keluarga antara lain intervensi keperawatan Mindfulness Spiritual Islam.
\end{abstract}

Kata kunci : intervensi keperawatan, self effycacy, keluarga skizofrenia

\section{NURSING INTERVENTION OF FAMILY SELF EFFICACY SKIZOFRENIA PATIENTS}

\begin{abstract}
The family is an affected parent directly from a family member with schizophrenia. Families also suffer from schizophrenia, even schizophrenia is a disorder that can last a lifetime, a heavy and prolonged financial and emotional burden on the family. Families bear the burden of stigma that tends to cling to families that have family members with schizophrenia.Families in treating schizophrenia need self efficacy. Nursing interventions are needed to improve family self-efficacy, strengthen coping strategies, prevent schizophrenia recurrence, improve family function and reduce family burden. This literature review aims to find out which interventions are used against family self-efficacy with schizophrenia. The method used uses a review of articles and nursing journals from 2007 to 2018. The results of various interventions conducted showed significant changes to self efficacy. Conclusions nurses need to know a variety of nursing interventions to family self efficacy to improve the ability of families to care for and receive patients with schizophrenia. Suggestions need to be developed nursing interventions to further improve the family efficacy, including Islamic Spiritual Mindfulness nursing interventions.
\end{abstract}

Keywords: nursing interventions, self effycacy, schizophrenia family

\section{PENDAHULUAN}

Gangguan mental menjadi masalah kesehatan serius yang dihadapi oleh setiap negara termasuk Indonesia. Skizofrenia adalah gangguan mental kronis yang mempengaruhi cara berpikir, perilaku, dan ditandai oleh gejala psikotik yang jelas seperti halusinasi, agitasi, insomnia, dan lain-lain serta memerlukan proses panjang dan mempengaruhi seluruh aspek kehidupan pasien. Skizofrenia menjadi 
salah satu penyakit yang berkontribusi pada beban penyakit global (Fischer dan Buchanan, 2016). Skizofrenia menyebabkan terjadinya kemunduran pada kesehatan fisik yang mungkin disertai dengan komplikasi, penurunan fungsi kognitif, defisit pada kinerja/ keterampilan psikomotorik, dan mengurangi tingkat kemandirian (Strassing et al., 2014).

Pasien skizofrenia tidak mampu menjalankan kegiatan sehari-hari dengan baik dan memerlukan bantuan orang lain dalam merawat keseharian mereka (Prianto, 2005 dalam Fitrikasari et al., 2012). Keluarga merupakan perawat utama yang memiliki peran penting dalam membantu pemulihan terhadap pasien skizofrenia. Akan tetapi, dalam merawat pasien skizofrenia, keluarga memiliki beban tersendiri yang berpengaruh terhadap psikologis keluarga dan keluarga berisiko mengalami gangguan mental (Geriani et al., 2015; Gupta et al., 2014; Lesibikan dan Ayinde, 2013).

Keluarga sering menyembunyikan pasien skizofrenia dari lingkungan masyarakat, mengurung dan membawa berobat "orang pintar". Dampak yang muncul adalah kekambuhan seumur hidup sehingga klien Skizofrenia memerlukan perawatan jangka panjang, dan menimbulkan dampak lain yaitu klien skizofrenia menjadi ketergantungan terhadap orang lain terutama kepada keluarga (Hawari, D.2007).

Skizofrenia berdampak signifikan pada seluruh keluarga dan secara nyata mengubah hidup keluarga. Perubahan yang terjadi meliputi peningkatan tanggung jawab keluarga, tanggung jawab emosional termasuk berusaha untuk menjaga keluarga utuh, pemantauan yang terus menerus terhadap keadaan mental dari anggota keluarga, dan penyediaan intervensi yang mendukung. Tanggung jawab keluarga meliputi pemantauan keuangan, kepatuhan pengobatan, penyediaan makanan, tempat tinggal, bantuan transportasi, dan biaya kunjungan ke pelayanan kesehatan mental (Mc Auliffe, 2009 dalam PH, Hermanto, Pratama, 2018).

Keluarga dengan salah satu anggota keluarga yang menderita gangguan jiwa Skizofrenia dapat mengalami beban psikologis bagi keluarga tersebut, beban ini terjadi karena keluarga tidak memiliki pemahaman akan kebutuhan pasien, tingkah laku pasien, sehingga mempersulit terjalinnya hubungan antara keluarga dan komunikasi dengan klien ( Wanti Y, et al, 2016).

Adanya stigma yang buruk dari masyarakat, bahwa skizofrenia adalah penyakit yang sulit disembuhkan dan aib bagi keluarga, hal ini bukan hanya menimbulkan konsekuensi negatif bagi penderita, tetapi juga dapat menimbulkan persepsi yang negatif bagi keluarga sehingga muncullah sikap penolakan, sikap penyangkalan, disisihkan maupun di isolasi, memiliki anggota keluarga dengan skizofernia bukanlah suatu hal yang mudah.(Irmansyah, 2006).

Keluarga yang merawat klien Skizofrenia memerlukan dukungan supaya memiliki self efficacy. Self efficacy merupakan suatu keyakinan dan diiringi kepercayaan atas dasar kemampuannya, sehingga dapat melakukan sebuah kontrol dengan batasan mereka sendiri dari fungsi dan atas peristiwa (Zakeri A, et al, 2016). Self efficacy mengacu pada suatu keyakinan bahwa individu mempunyai kapasitas mereka sendiri untuk mengatur dan melaksanakan program tindakan yang diperlukan untuk menghasilkan hasil yang diinginkan. Self-efficacy mampu untuk merubah perilaku, memotivasi anggota keluarga belajar memberikan perawatanyang terbaik, dan menjaga dari kekambuhan. Self efficacy mempengaruhi perilakukeluarga, seperti tidak ditemukan lagipengurungan terhadap klien Skizofernia (Perez et al, 2011).

Literatur review ini memiliki tujuan untuk mengetahui intervensi keperawatan yang digunakan terhadap keyakinan diri keluarga/ self efficacy keluarga terhadap pasien skizofrenia melalui studi literature review.

\section{METODE}

Metode yang digunakan dalam penulisan ini merupakan studi literature review. Sumber pustaka yang digunakan dalam penyusunan literature ini menggunakan artikel dengan proses pencarian artikel database dan Jurnal keperawatan. Tahun penerbitan artikel yang digunakan adalah tahun 2007 sampai tahun 2018. Jumlah artikel yang digunakan ada 17 artikel. 


\section{HASIL}

Hasil penelitian dari Fitrikasri et. Al ( 2012) Sebanyak 89 responden keluarga pasien dengan skizofrenia (89\%) merasa terbebani dengan kondisi pasien skizofrenia. Beban terberat adalah dampak terhadap rasa nyaman, merasa berat dengan masalah yang dihadapi, dampak terhadap hubungan dengan orang lain, apresiasi terhadap peran perawatan dan dampak terhadap kualitas hubungan perkawinan.Sebagian besar keluarga menganggap perawatan terhadap anggota keluarga dengan gangguan skizofrenia sebagai beban dalam kehidupan mereka. Hasil dari penelitian Adriyani et. Al (2017), menyebutkan bahwa self efficacy mempengaruhi kualitas hidup yang lebih baik baik bagi keluarga pasien skizofrenia.

Hasil penelitian Kartikasari (2017 menunjukkan terdapat perubahan bermakna self efficacy keluarga dengan sosial okupasi klien skizofrenia setelah diberikan terapi psikoedukasi $\mathrm{p}<0,05)$ dan terdapat perbedaan perubahan bermakna pada kelompok kontrol dan intervensi $(\mathrm{p}<0,05)$. Dari penelitian ini, peneliti merekomendasikan penggunaan terapi psikoedukasi keluarga sebagai terapi modalitas pada keluarga yang merawat klien skizofrenia. Hasil dari penelitian Ah. Yusuf (2013) menyebutkan bahwa pemberian terapi keluarga dengan pendekatan spiritual dapat meningkatkan model keyakinan kesehatan keluarga dalam merawat pasien dengan gangguan mental skizofrenia . Sampel sebanyak 13 orang di setiap kelompok perlakuan dan kelompok kontrol. Intervensi diberikan selama 60-120 menit dalam 8 kali pertemuan dengan interval rata-rata sekitar 1 minggu.

Hasil penelitian Pratama BD, 2017 Pengetahuan keluarga pasien gangguan jiwa di RSJD Dr. RM. Soedjarwadi adalah cukup, efikasi diri keluarga pasien gangguan jiwa di RSJD Dr. RM. Soedjarwadi adalah sedang. Ada hubungan korelasi yang signifikan pengetahuan dengan efikasi diri pada caregiver keluarga pasien gangguan jiwa di RSJD Dr. RM. Soedjarwadi. Penelitian yang dilakukan oleh Murtoyo, et all (2018) menyebutkan psikoedukasiterapi keluarga dengan Calcagy Family Intervention Model (CFIM) efektif dalam meningkatkan effikasi keluarga dengan skizofren.

\section{PEMBAHASAN}

Sebagian besar keluarga mempunyai persepsi dan pemikiran bahwa skizofrenia adalah sebuah penyakit yang memalukan bagi keluarga. Hal ini dikarenakan ketidaktahuan keluarga dalam melakukan intervensi pada anggota keluarganya yang sedang sakit. Keluarga juga merasa tidak nyaman dan harus bisa melakukan suatu tindakan agar klien dapat sembuh kembali. Keluarga pun merasa malu terhadap anggapan negatif dari tetangga sekitar tentang anggota keluarganya yang mengalami skizofrenia (Komariyah, 2014)

Keluarga merupakan orang-orang yang terkena dampak langsung dari kehadiran skizofrenia dalam kehidupan keluarga. Oleh karena itu keluarga merupakan pihak yang menderita seperti halnya pasien skizofrenia, bahkan skizofrenia merupakan gangguan yang dapat berlangsung seumur hidup pasien, sehingga merupakan beban finansial dan emosional yang berat dan berkepanjangan bagi keluarga. Keluarga juga menanggung beban stigma yang cenderung melekat pada keluarga yang memiliki anggota keluarga penderita skizofrenia (Gunarsa, 2012).

Besarnya peranan pasien skizofrenia dalam keluarga maupun masyarakat menentukan besarnya dampak terhadap fungsi sosial, ekonomi, keluarga dan masyarakat apabila individu tersebut menderita skizofrenia. Kalau pasien skizofrenia sebagai orang tua yang menentukan dalam status sosial dan ekonomi keluarga, akan menyebabkan menurun atau memburuknya fungsi sosial ekonomi keluarga tersebut. Hal ini menghadapkan keluarga dalam berbagai masalah seperti kemiskinan, pertengkaran dan kriminalitas. Demikian pula jika penderita adalah sebagai anak membawa beban yang cukup berat bagi orang tua karena perjalanan penyakitnya yang bersifat kornik residif bahkan cenderung progresif, sejalan dengan itu kemampuan orang tua semakin berkurang dalam merawat dan mengobati penderita karena produktivitas yang semakin berkurang dengan bertambahnya usia (Dharmabrata, 2013). 
Keluarga dalam merawat pasien skizofrenia membutuhkan self efficacy. Penelitian Pratama (2017) menyatakan bahwa sebagian besar $(55,8 \%)$ care giver keluarga mempunyai self efficacy sedang. Self efficacy keluarga pasien gangguan jiwa mencakup aspek merawat pasien defisit perawatan diri, merawat pasien harga diri rendah, merupakan pasien isolasi sosial, merawat pasien halusinasi, merawat pasien dengan kekerasan, melakukan pengobatan dan terapi psikososial.

Menurut Albert Bandura, Self-efficacy merupakan salah satu aspek pengetahuan tentang diri atau self knowledge yang paling berpengaruh dalam kehidupan manusia seharihari. Hal ini disebabkan self-efficacy yang dimiliki ikut mempengaruhi individu dalam menentukan tindakan yang akan dilakukan untuk mencapai suatu tujuan termasuk di dalamnya perkiraan berbagai kejadian yang akan dihadapi. Self-efficacy yakni keyakinan bahwa seseorang dapat menguasai situasi dan mendapatkan hasil positif (Stanley M, 2013).

Hasil penelitian Nasriati (2016) diperoleh bahwa sebagian besar (52\%) keluarga penderita gangguan jiwa mengalami stigma tinggi dan sebagian besar $(60 \%)$ responden memberikan dukungan keluarga yang buruk pada penderita gangguan jiwa. Stigma tinggi yang dirasakan oleh keluarga akan berdampak pada peningkatan beban keluarga, meningkatnya stress dan berpengaruh terhadap kualitas hidup serta depresi. Untuk itu keluarga perlu mendapatkan terapi keluarga untuk memperkuat strategi koping dalam menangani perubahan mental klien, mencegah kekambuhan serta mempertahankan keberadaan klien di masyarakat. Therapi keluarga mampu meningkatkan fungsi keluarga dan menurunkan beban keluarga, mengurangi kekambuhan dan memperbaikikemandirian (Chien, T.W., \& Wong, F, 2007).

\section{SIMPULAN}

Selft efficacy keluarga penting untuk meningkatkan fungsi keluarga dan menurunkan beban keluarga. Sebagian besar menyebutkan bahwa dari berbagai intervensi yang dilakukan secara signifikan mampu menigkatkan selft efficacy keluarga.
Keluarga dengan self efficacy tinggi, percaya bahwa akan mampu melakukan sesuatu untuk mengubah kejadian-kejadian di sekitarnya, sedangkan dengan self efficacy rendah merasa tidak mampu mengerjakan segala sesuatu yang ada di sekitarnya. Dalam situasi yang sulit, orang dengan self efficacy rendah cenderung mudah menyerah, sedangkan orang dengan self efficacy tinggi akan berusaha lebih keras untuk mengatasi tantangan yang ada.

\section{DAFTAR PUSTAKA}

Adriani RB, Rahardjo SS. Effect of Locus of Control, Self-Efficacy, and Personality Type on the Quality of Life among Caregivers of Schizophrenia Patient in Godean Sub-District , Yogyakarta. 2017;2:20-31.

Ah.Yusuf S (2013) Terapi keluarga dengan pendekatan spiritual terhadap model keyakinan kesehatan keluarga dalam merawat pasien skizofrenia. Fakultas Keperawatan Universitas Airlangga

Dharmabrata, 2013, Psikiatri Forensik, Penebit PT. EGC, Jakarta

Dwidiyanti, 2018, Mindfulness untuk SelfCare. In: Meidiana Dwidiyanti, Reza Indra Wiguna HEWN, Undip Press, Semarang

Murtoyo E, et al (2018) Efektifitas Psikoedukasi Terapi Keluarga Dengan Calgary Family Intervention Model (CFIM) terhadap Peningkatan Effikasi Keluarga sebagai Caregiver Orang Dengan Skizofrenia(ODS). Jurnal Ners dan Kebidanan Indonesia Universitas Alma Ata Yogyakarta.

Fischer BA, Buchanan RW (2016). Schizophrenia: Epidemiology and pathogenesis. Dalam http://www.uptodate.com/contents/schizophreniaepidemiology-and-pathogenesis. Diakses 23 Oktober 2016.

Fitrikasari A, Kadarman A, Sarjana W (2012). Gambaran Beban Caregiver Penderita Skizofrenia di Poliklinik Rawat Jalan RSJ Amino Gondohutomo Semarang. Medica Hospitalia, 1(2): 118-122.

Geriani D, Savithry KSB, Shivakumar S, \& Kanchan T (2015). Burden of Care on 
Caregivers of Schizophrenia Patients: A Correlation to Persona- lity and Coping. Journal of Clinical and Diagnostic Research: JCDR, 9(3): 01-04.

Gupta A, Solanki RK, Koolwal GD \& Gehlot S (2014). Psychological Well- Being and Buden in Caregivers of Patients with Schizophrenia. Inter- national Journal of Medical Science and Public Health, 4: 70-76.

Gunarsa, 2012, Bunga Rampai Psikologi Perkembangan: Dari Anak Sampai Usia Lanjut, Penerbit PT. BPK Gunung Mulia, Jakarta

Hawari, D. (2007). Pendekatan holistik padagangguan jiwa skizofrenia. Jakarta: BalaiPenerbit FKUI.

Irmansyah. (2006). Pencegahan danintervensi dini skizofrenia. Retrieved from http://64.203.71.11/kompascetak/0410/1 9/ ilpeng/1331282.htm, 12 April 2015

Kartikasari R, Yosep I, Sriati A. (2017) The Influence of Family Psychoeducation Therapy on Self Efficacy Family And Social Occupations Schizophrenia' $s$ Clients. 5:123-35.

PH. Livana, Hermanto, Pratama. Nanda Putra (2018) Dukungan Keluarga Dengan Perawatan Diri Pada Pasien Gangguan Jiwa Di Poli Jiwa. Jurnal Manarang 4(1).

http://www.jurnal.poltekkesmamuju.ac.i $\mathrm{d} /$ index.php/m/article/view/54

Nasriati, 2016, Stigma dan Dukungan Keluarga dalam Merawat Orang dengan Gangguan Jiwa, Fakultas Ilmu Kesehatan, Universitas Muhammadiyah Ponorogo, Ponorogo

Perez, JML., Medina, FJ dan Munduate, L., 2011, Effects of Self-Efficacy on Objective and Subjective Outcomes in Transactions and Disputes, University of Seville, Spain.

Pratama NP, Studi P, Keperawatan I, Tinggi S, Kesehatan I. Dukungan keluarga dengan perawatan diri pada pasien gangguan jiwa di poli jiwa. 2018;
Pratama BD,Widodo A,( 2017) ,Hubungan Pengetahuan Dengan Efikasi Diri Pada Caregiver Keluarga Pasien Gangguan Jiwa Di Rsjd Dr. Rm. Soedjarwadi. Fakultas Ilmu Kesehatan Universitas Muhammadiyah

Strassing M, Signorile J, Gonzales C, Harvey PD (2014). Physical Perfor- mance and Disability in Schizophre- nia. National Institute of Health Public Access, 1(2): 112-121.

Stanley M,Pollard D.(2013) Attitude and selft efficacy of nurse In The Management of Pediatric Pain.

Wanti Y, Widianti E, Fitria N. Gambaran Strategi Koping Keluarga dalam Merawat Anggota Keluarga yang Menderita Gangguan Jiwa Berat. ResearchGate [Internet]. 2017;(April 2016).

Zakeri, A., Rahmany, R dan Labone, E., 2016, Teachers' Self- and Collective Efficacy: The case of Novice English Language Teachers, Journal of Language Teaching and Research, Academy Publication 
Jurnal Keperawatan Jiwa Volume 7 No 2 Hal 197 - 202, Agustus 2019

FIKKes Universitas Muhammadiyah Semarang bekerjasama dengan PPNI Jawa Tengah 